\title{
Simvastatin increases clot permeability and susceptibility to lysis in patients with LDL cholesterol below $3.4 \mathrm{mmol} / 1$
}

\author{
Anetta Undas', Roman Topór-Mądry², Wiesława Tracz ${ }^{1}$ \\ 1 Institute of Cardiology, Jagiellonian University School of Medicine, Kraków, Poland \\ 2 Institute of Public Health, Jagiellonian University School of Medicine, Kraków, Poland
}

\section{KEY WORDS}

cholesterol, fibrin clot, fibrinolysis, statins
Correspondence to:

Prof. Anetta Undas, MD

$\mathrm{PhD}$, Instytut Kardiologii,

Uniwersytet Jagielloński,

Collegium Medicum, ul. Prądnicka 80,

31-202 Kraków, Poland,

phone: + 48-12-614-30-04

fax: +48-12-423-39-00,

e-mail: mmundas@cyf-kr.edu.pl

Received: April 23, 2009.

Accepted: May 7, 2009.

Conflict of interest: none declared.

Pol Arch Med Wewn. 2009;

119 (6): 354-359

Copyright by Medycyna Praktyczna,

Kraków 2009

\section{ABSTRACT}

INTRODUCTION Statins produce additional beneficial effects, including attenuation of prothrombotic mechanisms. In patients at high cardiovascular risk, who have markedly elevated low-density lipoprotein (LDL) cholesterol levels, simvastatin can reduce thrombin generation. Moreover, we have described simvastatin-induced improvement of fibrin clot properties, the formation of which represents the final step of blood coagulation.

OBJECTIVES The aim of the present study was to assess the effect of simvastatin on fibrin features observed in subjects with LDL cholesterol $<3.4 \mathrm{mmol} / \mathrm{l}$.

PATIENTS AND METHODS Thirty subjects $(24 \mathrm{M}, 6 \mathrm{~F})$ aged $<70$ years with $\mathrm{LDL}$ cholesterol $<3.4 \mathrm{mmol} / \mathrm{l}$ with no history of cardiovascular events were enrolled in the study. Patients were excluded if they had diabetes mellitus, chronic inflammatory diseases and renal insufficiency. Prior to and following a 3-month treatment with simvastatin $(40 \mathrm{mg} / \mathrm{d})$, ex vivo plasma fibrin clot permeability and efficiency of clot lysis were measured.

RESULTS Simvastatin led to a significant decrease in total cholesterol, LDL cholesterol, triglycerides and C-reactive protein (CRP), while fibrinogen levels remained unaltered. There were posttreatment increase in clot permeability by $4.4 \%(p<0.001)$ and shortening of clot lysis by $11.2 \%(p<0.001)$ compared to pretreatment values. These changes were correlated with reduction in CRP following simvastatin. Simvastatin-induced increase in clot permeability was associated only with age and decrease in CRP levels ( $R^{2}$ for the model $=0.61$ ), while shortening of clot lysis time observed following simvastatin use was predicted only by reduction of triglycerides and $C R P\left(R^{2}\right.$ for the model $=0.62$ ).

CONCLUSIONS Simvastatin exerts unique properties involving enhanced fibrin clot lysis and increased clot permeability in subjects with $\mathrm{LDL}$ cholesterol $<3.4 \mathrm{mmol} / \mathrm{l}$, which is associated with its anti-inflammatory effects. Altered fibrin clot function might contribute to clinical benefits of statins.

INTRODUCTION The final steps in the blood coagulation process, fibrinogen conversion to fibrin and fibrin monomer cross-linking by activated factor XIII, result in the formation of a clot, which is relatively resistant to mechanical and enzymatic degradation. ${ }^{1}$ Fibrin clot structure affects transport of macromolecules through networks, including proteins involved in fibrinolysis and has a stronger effect on fibrinolysis rate than fiber thickness. ${ }^{2}$ Altered fibrin clot architecture and function have been reported in patients with cardiovascular pathologies, including acute phase of myocardial infarction (MI), ${ }^{3}$ history of $\mathrm{MI}^{4}$, or cryptogenic ischemic stroke ${ }^{5}$. Fibrin clot properties are modulated by several genetic and environmental factors, predominantly those affecting levels and function of fibrinogen. ${ }^{6}$

Statins are highly effective in the prevention of cardiovascular events in various patient populations and exert several additional beneficial 
TABLE 1 Characteristics of the study subjects at baseline and following a 3-month administration of simvastatin $(40 \mathrm{mg} / \mathrm{d})$

\begin{tabular}{llll} 
& $\begin{array}{c}\text { Prior to } \\
\text { simvastatin } \\
(\mathrm{n}=30)\end{array}$ & $\begin{array}{l}\text { Following } \\
\text { simvastatin }\end{array}$ & $\mathrm{n}=30)$ \\
\hline age $(\mathrm{yrs})$ & $51.7 \pm 7.6$ & - & - \\
\hline male gender, $\mathrm{n}(\%)$ & $30(100)$ & - & - \\
\hline BMl $\left(\mathrm{kg} / \mathrm{m}^{2}\right)$ & $31.2 \pm 2.8$ & - & - \\
\hline smoking, $\mathrm{n}(\%)$ & $8(26.7)$ & - & - \\
\hline hypertension, $\mathrm{n}(\%)$ & $11(36.7)$ & - & - \\
\hline fibrinogen $(\mathrm{g} / \mathrm{l})$ & $2.78 \pm 0.49$ & $2.74 \pm 0.44$ & 0.12 \\
\hline TC $(\mathrm{mmol} / \mathrm{l})$ & $4.99 \pm 0.51$ & $4.32 \pm 0.38$ & $<0.001$ \\
\hline LDL-C $(\mathrm{mmol} / \mathrm{l})$ & $2.94 \pm 0.43$ & $2.35 \pm 0.32$ & $<0.001$ \\
\hline $\mathrm{HDL}-\mathrm{C}(\mathrm{mmol} / \mathrm{l})$ & $1.42 \pm 0.24$ & $1.43 \pm 0.22$ & 0.6 \\
\hline triglycerides $(\mathrm{mmol} / \mathrm{l})$ & $1.31 \pm 0.41$ & $1.16 \pm 0.30$ & $<0.001$ \\
\hline glucose $(\mathrm{mmol} / \mathrm{l})$ & $4.87 \pm 0.51$ & $4.97 \pm 0.49$ & 0.2 \\
\hline $\mathrm{creatinine}(\mu \mathrm{mol} / \mathrm{l})$ & $75.97 \pm 14.02$ & $75.10 \pm 13.07$ & 0.3 \\
\hline $\mathrm{CRP}(\mathrm{mg} / \mathrm{l})$ & $1.89 \pm 0.82$ & $1.64 \pm 0.66$ & $<0.001$ \\
\hline $\mathrm{K}_{\mathrm{s}}\left(10^{-9} \mathrm{~cm}{ }^{2}\right)$ & $10.0 \pm 1.12$ & $10.44 \pm 1.05$ & $<0.001$ \\
\hline $\mathrm{t}(\mathrm{min})$ & $115.5 \pm 15.5$ & $102.6 \pm 11.0$ & $<0.001$ \\
\hline & & &
\end{tabular}

Data are given as mean $\pm \mathrm{SD}$, unless otherwise stated.

Abbreviations: CRP - C-reactive protein, HDL-C - high-density lipoprotein cholesterol, LDL-C - low-density lipoprotein cholesterol, $\mathrm{K}_{\mathrm{s}}$ - clot permeability, $\mathrm{t}$ - clot lysis time, TC - total cholesterol unstable angina were enrolled in the study. Inclusion criteria were LDL cholesterol $<3.4 \mathrm{mmol} / \mathrm{l}$ and $\mathrm{C}$-reactive protein $(\mathrm{CRP})<5 \mathrm{mg} / \mathrm{l}$. Exclusion criteria were as follows: diabetes mellitus, any acute illness, known cancer, hepatic or renal dysfunction, anticoagulant therapy, acute coronary syndrome within 6 months before the start of the study, treatment for hyperlipidemia or with angiotensin converting enzymeinhibitors not later than 6 weeks preceding the enrollment. Patients taking aspirin or thienopyridines were also excluded. Given the data on abnormal fibrin structure in relatives of patients with premature $\mathrm{MI}^{14}$, we excluded individuals with MI or stroke among first-degree relatives.

All study participants received simvastatin (Zocor, Merck Sharp and Dohme) $40 \mathrm{mg} /$ day on an open-label basis for $90 \pm 12$ days.

The University Ethical Committee approved the study, and patients provided written, informed consent.

Laboratory investigations Blood samples were collected to $0.11 \mathrm{~mol} / \mathrm{L}$ trisodium citrate $(9: 1$, $\mathrm{v} / \mathrm{v}$ ) from all subjects at enrollment, and then at the end of simvastatin administration. Lipid profiles, glucose, creatinine, aminotransferases, and creatine kinase were assayed by routine laboratory techniques. Plasma and serum samples were centrifuged within 60 minutes at $20^{\circ} \mathrm{C}$ and stored in aliquotes at $-80^{\circ} \mathrm{C}$ to allow batch anal ysis. Fibrinogen concentrations were determined using the Clauss method. High-sensitivity CRP levels were measured by an immunoturbidimetric method (Dade Behring). All the intra-assay coefficients of variation were below $7 \%$.

Fibrin clot permeability Permeation properties of fibrin clots were investigated according to Mills et al. ${ }^{14}$ in our modification ${ }^{3,13}$. Briefly, $20 \mathrm{mmol} / \mathrm{L}$ calcium chloride and $1 \mathrm{U} / \mathrm{mL}$ human thrombin (Sigma) were added to citrated plasma. After 2 hours of incubation at room temperature in a wet chamber, tubes containing the clots were connected to a reservoir of a buffer (0.01 M Tris, 0.1 $\mathrm{M} \mathrm{NaCl}, \mathrm{pH}$ 7.5) and its volume flowing through the gels was measured within 60 minutes. Bromophenol blue was applied to the clot after experiments to detect potential leaks and defective clots were discarded. A permeation coefficient $\left(\mathrm{K}_{\mathrm{s}}\right)$, which indicates the pore size, was calculated from the equation: $\mathrm{K}_{\mathrm{s}}=\mathrm{QxLx} \eta / \mathrm{txAx} \Delta \mathrm{p}$, where $\mathrm{Q}$ is the flow rate in time $t, \mathrm{~L}$ is the length of a fibrin gel, $\eta$ is the viscosity of liquid (in poise), $A$ is the cross-sectional area (in $\mathrm{cm}^{2}$ ), and $\Delta \mathrm{p}$ is a dif ferential pressure (in dyne $/ \mathrm{cm}^{2}$ ). The interassay and intraassay variability of results was $7.2 \%$.

Plasma clot formation and fibrinolysis Fibrinolysis by exogenous recombinant tissue plasminogen activator, rt-PA (Boerhinger Ingelheim), was evaluated using an assay developed by van dem Borne et al. ${ }^{15}$ Briefly, citrated plasma was mixed (1:1) with HEPES buffer, containing calcium 
TABLE 2 Correlations between the permeability coefficient and lysis time and other variables prior to (panel $A$ ) and following a 3-month simvastatin administration (panel B)

PANEL A

\begin{tabular}{|c|c|c|c|c|}
\hline & \multicolumn{2}{|l|}{$\mathrm{K}_{\mathrm{s}}$} & \multicolumn{2}{|l|}{$\mathrm{t}$} \\
\hline & \multirow[t]{2}{*}{ correlation, r } & $\mathrm{p}$ & \multirow[t]{2}{*}{ correlation, r } & $\mathrm{p}$ \\
\hline & & (2-tailed) & & (2-tailed) \\
\hline $\mathrm{K}_{\mathrm{s}}$ & 1 & & -0.504 & $\underline{0.01}$ \\
\hline $\mathrm{t}$ & -0.504 & $\underline{0.01}$ & 1 & \\
\hline age & 0.226 & 0.23 & -0.162 & 0.39 \\
\hline smoking & 0.333 & 0.07 & -0.339 & 0.07 \\
\hline creatinine & -0.03 & 0.87 & -0.152 & 0.45 \\
\hline glucose & 0.073 & 0.7 & -0.045 & 0.81 \\
\hline TG & -0.064 & 0.74 & 0.112 & 0.56 \\
\hline TC & -0.207 & 0.27 & 0.065 & 0.73 \\
\hline HDL-C & -0.111 & 0.56 & 0.141 & 0.46 \\
\hline LDL-C & -0.096 & 0.61 & 0.046 & 0.81 \\
\hline CRP & $-\underline{0.481}$ & $\underline{0.01}$ & $\underline{0.639}$ & $<\underline{0.01}$ \\
\hline fibrinogen & $-\underline{0.774}$ & $<\underline{0.01}$ & $\underline{0.558}$ & $<\underline{0.01}$ \\
\hline
\end{tabular}

PANEL B

\begin{tabular}{lllll} 
& & & $\mathrm{t}$ & \\
& correlation, $\mathrm{r}$ & $\mathrm{p}$ & correlation, $\mathrm{r}$ & $\mathrm{p}$ \\
(2-tailed) & & $\underline{0.01}$ \\
\hline $\mathrm{K}_{\mathrm{s}}$ & 1 & & -0.491 & \\
\hline $\mathrm{t}$ & $-\underline{0.491}$ & $\underline{0.01}$ & 1 & 0.18 \\
\hline age & 0.367 & 0.05 & -0.253 & 0.14 \\
\hline smoking & $\underline{0.378}$ & $\underline{0.04}$ & -0.274 & 0.40 \\
\hline creatinine & 0.097 & 0.61 & -0.161 & 0.77 \\
\hline glucose & 0.054 & 0.78 & 0.056 & 0.05 \\
\hline TG & -0.011 & 0.95 & 0.355 & 0.48 \\
\hline TC & -0.214 & 0.26 & 0.133 & 0.63 \\
\hline HDL-C & 0.014 & 0.94 & -0.092 & 0.76 \\
\hline LDL-C & -0.246 & 0.19 & 0.058 & $<\underline{0.01}$ \\
\hline CRP & $-\underline{0.377}$ & $\underline{0.04}$ & $\underline{0.564}$ & $\underline{0.01}$ \\
\hline fibrinogen & $-\underline{0.733}$ & $<\underline{0.01}$ & $\underline{0.463}$ & \\
\hline
\end{tabular}

Significant correlations $(p<0.05)$ are underlined.

Abbreviations: $r$ - correlation coefficient, TG - triglycerides, others - see TABLE 1

chloride, diluted recombinant tissue factor (Innovin, Dade Behring), phospholipid vesicles, prepared as described ${ }^{16}$, and rt-PA (Boerhinger Ingelheim). This mixture $(100 \mu \mathrm{L})$ was transferred to a microtiter reader and turbidity was measured at $405 \mathrm{~nm}$ at $37^{\circ} \mathrm{C}$ in a Spectramax 340 kinetic microplate reader (Molecular Devices Corp., Menlo Park, CA). Clot lysis time was defined as the time from the midpoint of the baseline clear to maximum turbid transition, to the final plateau phase. The interassay and intraassay coefficients of variation were 8.1 and $6.2 \%$, respectively.

Statistical analysis Data are expressed as mean $( \pm S D)$ or otherwise stated. Categorical values were compared using the $\chi^{2}$ test, and paired t test was used to test differences in continuous data between groups. The effect of simvastatin was analyzed using Wilcoxon signed rank test for non-normally distributed data, otherwise with paired $t$ test. Pearson correlation coefficient was calculated to test the association between 2 variables. The level of significance was set at $\mathrm{p}<0.05$.

RESULTS The baseline characteristics of the patients are shown in TABLE 1. Simvastatin reduced total cholesterol by $13.4 \%$ and LDL cholesterol by $20.1 \%$ (TABLE 1). Triglyceride levels became significantly lower following administration of simvastatin with no change in high-density lipoprotein cholesterol at day 90 (TABLE 1). Fibrinogen levels did not change following statin administration, while CRP levels were reduced significantly (TABLE 1). Other blood routine parameters remained unaltered (TABLE 1). Safety laboratory measures also remained unchanged following statin treatment (data not shown). No adverse events were observed within a 3-month period of time.

Clot permeability At baseline, fibrin clot permeability was relatively low and increased following administration of simvastatin (by $4.4 \%$; $\mathrm{p}<0.01$ ) as shown in TABle 1 (panel A). A mean posttreatment increase in $\mathrm{K}_{\mathrm{s}}$ values was $0.4410^{-9}$ $\mathrm{cm}^{2}$ (95\% CI -0.54 to $\left.-0.3410^{-9} \mathrm{~cm}^{2}\right)$.

As expected, baseline clot permeability was negatively correlated with fibrinogen $(r=-0.72$; $\mathrm{p}<0.0001$ ) and CRP levels with a lower $r$ value (tABle 2, PANel A). No other associations were observed for $K_{s}$ (TABLE 2, PANEL A).

Posttreatment permeability coefficient showed similar associations (TABLE 2, PANel B).

Simvastatin-induced increase in clot permeability showed significant associations only with decreases in CRP and total cholesterol as well as age (TABLE 3).

Clot lysis Turbidimetric analysis of clot assembly and fibrinolysis revealed that clot lysis time was relatively long before the start of therapy and decreased significantly by $11.2 \%$ following therapy (TABLE 1). A mean shortening in lysis time was $12.9 \mathrm{~min}$ (95\% CI 10.3 to $15.5 \mathrm{~min}$ ).

Posttreatment lysis time showed similar associations (TABLE 2, PANEL B).

Analysis of associations between simvastatin-induced changes in the laboratory parameters (TABLE 3) showed that the magnitude of decreases in lysis time is associated with changes in serum CRP levels. Moreover there was a significant correlation between increases in lysis time and reduction in triglycerides observed following simvastatin administration. Other laboratory variables showed no associations with the changes in lysis time (TABLE 3).

Multiple regression analysis To identify variables that are independently associated with fibrin clot variables, the multiple regression analysis was 
TABLE 3 Correlations between changes in the permeability coefficient $\left(\mathrm{K}_{\mathrm{s}}\right)$ and lysis time and those in other variables observed following a 3-month simvastatin administration in 30 subjects

\begin{tabular}{|c|c|c|c|c|}
\hline & \multicolumn{2}{|l|}{$\Delta \mathrm{K}_{\mathrm{s}}$} & \multicolumn{2}{|l|}{$\Delta \mathrm{t}$} \\
\hline & correlation, r & p (2-tailed) & correlation, r & p (2-tailed) \\
\hline$\Delta \mathrm{K}_{\mathrm{s}}$ & 1 & & -0.327 & 0.08 \\
\hline$\Delta \mathrm{t}$ & -0.327 & 0.08 & 1 & \\
\hline$\Delta \mathrm{TG}$ & -0.151 & 0.43 & -0.339 & 0.07 \\
\hline$\Delta$ creatinine & -0.217 & 0.25 & 0.034 & 0.86 \\
\hline$\Delta \mathrm{TC}$ & $-\underline{0.448}$ & $\underline{0.01}$ & 0.100 & 0.60 \\
\hline$\Delta \mathrm{HDL}-\mathrm{C}$ & -0.324 & 0.08 & 0.297 & 0.11 \\
\hline$\Delta \mathrm{LDL}-\mathrm{C}$ & -0.297 & 0.11 & 0.171 & 0.37 \\
\hline$\Delta \mathrm{CRP}$ & $-\underline{0.553}$ & $<\underline{0.01}$ & $\underline{0.453}$ & $\underline{0.01}$ \\
\hline$\Delta$ fibrinogen & -0.182 & 0.34 & 0.034 & 0.86 \\
\hline
\end{tabular}

Significant correlations $(p<0.05)$ are underlined.

Abbreviations: see TABLES 1 and 2

performed. As shown in TABLE 4, simvastatin-induced increase in clot permeability was associated only with age and decrease in CRP levels $\left(\mathrm{R}^{2}\right.$ for the model $=0.61$ ), while shortening of clot lysis time observed following simvastatin use was predicted only by reduction of triglycerides and CRP $\left(\mathrm{R}^{2}\right.$ for the model $=0.62$ ).

DISCUSSION The current study demonstrates that simvastatin used commonly in atherosclerotic vascular disease can favorably affect plasma clot architecture in low-risk subjects. Our data provide evidence that statin-induced slightly, but significantly faster lysis, indicating more effective lysis of the plasma clots formed, is linked with the formation of clots with loosely packed fibers, characterized by greater permeability. We observed significant increases in clot permeability following $90 \pm 12$ days of therapy with simvastatin $40 \mathrm{mg} / \mathrm{d}$. Interestingly, the magnitude of these effects was associated with the magnitude of reduction in serum CRP concentrations, but not cholesterol-lowering actions of simvastatin. The formation of more porous and lysable fibrin clots during treatment with statins represents their novel mechanism of action associated with suppression of inflammation that may have clinical implications in all thrombotic disorders.

In 2004, Scott et al. ${ }^{6}$ suggested that the use of some medications such as fibrates might lead to the formation of more porous clots because of reduced fibrinogen levels. Inconsistent reports on statin-induced changes in fibrinogen levels were also published. ${ }^{17-19}$ In the present study, simvastatin did not lower fibrinogen levels, therefore, the changes in clot permeability are not related to this variable. In 2006, Undas et al. ${ }^{13}$ demonstrated favorable effects of reduced CRP on fibrin clot permeability, but not clot lysis, in high-risk subjects. Importantly, in patients with LDL cholesterol $<3.4 \mathrm{mmol} / \mathrm{l}$ and CRP $<5 \mathrm{mg} / \mathrm{l}$, we observed significant associations between changes in both fibrin variables and decreases in serum CRP levels.
In the present study higher CRP levels at baseline were also associated with lower clot permeability and longer clot lysis. A pathophysiologic basis for these relationships is the in vitro study by $\mathrm{Sa}-$ lonen and coworkers ${ }^{20}$ showing that CRP binds to various proteins including fibrin(ogen). Our findings clearly indicate that at lower cholesterol levels and less enhanced low-grade inflammatory state typical of atherosclerosis, fibrin-modifying properties of simvastatin are more pronounced and might largely contribute to its antithrom botic effects demonstrated both in arterial and venous thrombotic disorders of high prevalence in the general population.

In contrast to Fatah et al., ${ }^{21}$ we failed to find significant associations between any lipid variables and clot permeability with one exception. Reduction in triglycerides following simvastatin showed association with lysis time, but not clot permeability. No such correlations were found in high-risk patients, in the stable and acute phase of CAD. ${ }^{3,13}$ Differences in patient population characteristics might be a reason for this discrepancy.

Our study has several limitations. First, the number of the patients enrolled was limited and the study was open-label with no control group receiving placebo or no treatment. However, all other factors known to affect fibrin properties remained unaltered following a 3-month statin therapy. Therefore the postreatment changes in clot properties are most likely associated with the intervention alone. Second, our analysis was restricted to two major fibrin variables. Other features have not been evaluated. Third, homocysteine and lipoprotein(a), which can alter fibrin properties ${ }^{22-24}$, have not been determined in this study. However, there is no consistent evidence showing reduced levels of both variables as a result of simvastatin treatment. Fourth, effects of statins on clot features have not been documented by means of other methods, e.g. using scanning electron microscopy. Fiber thickness and pore size estimated using this technique usually showed strong correlations with permeability and turbidimetric analysis of clot formation. ${ }^{4}$ On the other hand, using this technique, clots are fixed and further processed, therefore measurements are hard to be extrapolated to the in vivo situation, which was supported, for example, by inconclusive data from electron microscopy in patients on peritoneal dialysis. ${ }^{25}$ Fifth, since diabetic subjects were excluded, it is unclear whether similar effects of simvastatin could be observed in individuals with no clinically overt CAD, having average LDL cholesterol levels and suffering from diabetes type 2 . This common disease markedly alters fibrin clot structure and function as shown by Robert Ariëns' group ${ }^{6}$, therefore most likely statins will not modify these features potently enough to be detectable using our approach, which might explain doubts surrounding the issue of statin use in diabetics. ${ }^{26}$ Finally, our experimental approach did not allow to analyze 
TABLE 4 Multiple regression analysis with a posttreatment change in the permeability coefficient (panel A) and lysis time (panel B) as dependent variables

PANEL A

\begin{tabular}{lll} 
& $\beta$ & $p$ \\
(constant) & & 0.06 \\
\hline age & $\underline{0.449}$ & $\underline{0.02}$ \\
\hline$\Delta$ CRP & $-\underline{0.421}$ & $\underline{0.05}$ \\
\hline$\Delta \mathrm{TG}$ & 0.196 & 0.27 \\
\hline$\Delta$ creatinine & -0.136 & 0.38 \\
\hline$\Delta \mathrm{TC}$ & -0.334 & 0.13 \\
\hline$\Delta$ HDL-C & -0.227 & 0.22 \\
\hline$\Delta \mathrm{LDL}-\mathrm{C}$ & 0.167 & 0.46 \\
\hline$\Delta$ fibrinogen & 0.119 & 0.47 \\
\hline
\end{tabular}

PANEL B

\begin{tabular}{lll} 
& $\beta$ & $p$ \\
(constant) & & $<0.001$ \\
\hline$\Delta \mathrm{TG}$ & $-\underline{0.717}$ & $<\underline{0.001}$ \\
\hline$\Delta \mathrm{CRP}$ & $-\underline{0.810}$ & $<\underline{0.001}$ \\
\hline$\Delta$ creatinine & 0.102 & 0.47 \\
\hline$\Delta \mathrm{TC}$ & -0.064 & 0.75 \\
\hline$\Delta \mathrm{HDL}-\mathrm{C}$ & 0.074 & 0.66 \\
\hline$\Delta$ LDL-C & -0.055 & 0.80 \\
\hline$\Delta$ fibrinogen & -0.086 & 0.59
\end{tabular}

Significant correlations $(p<0.05)$ are underlined.

Abbreviations: see TABLES 1 and 2

the effect of blood cells and platelets on fibrin clot structure/function, which can markedly alter for example fibrinolysis. ${ }^{27}$

In conclusion, our results suggest that in normocholesterolemic subjects with no evidence of enhanced inflammation, statins increase plasma clot permeability following a 3-month therapy, and these effects are unrelated to any changes in fibrinogen levels. Importantly, improved permeability is associated with significant acceleration of clot lysis. These additional antithrombotic mechanisms reported here can in part account for reduction in thrombotic complications of atherosclerosis in patients treated with statins, together with other thrombin lowering associated effects that have been convincingly demonstrated for simvastatin. ${ }^{28}$ To what extent altered fibrin structure and function with the resultant increased clot lysability may contribute to clinical benefits of statins in arterial and venous thrombosis, remains to be established.

Acknowledgments This work was supported by the Institution Grant of the Jagellonian University School of Medicine (PKL/612/L). We would like to acknowledge Merck Sharp and Dohme for providing the study medication.

\section{REFERENCES}

1 Mosesson MW, Siebenlist KR, Meh DA. The structure and biological features of fibrinogen and fibrin. Ann NY Acad Sci. 2001; 936: 11-30.

2 Collet JP, Lesty C, Montalescot G, et al. Dynamic changes of fibrin architecture during fibrin formation and intrinsic fibrinolysis of fibrin-rich clots J Biol Chem. 2003; 278: 21331-21335.

3 Undas A, Szuldrzynski K, Stepien E, et al. Reduced clot permeability and susceptibility to lysis in patients with acute coronary syndrome: Effects of inflammation and oxidative stress. Atherosclerosis. 2007; 196: 551-558.

4 Collet JP, Allali Y, Lesty C, et al. Altered fibrin architecture is associated with hypofibrinolysis and premature coronary atherothrombosis. Arterioscler Thromb Vasc Biol. 2006; 26: 2567-2573.

5 Undas A, Podolec $\mathrm{P}$, Zawilska $\mathrm{K}$, et al. Altered fibrin clot structure/function as a novel risk factor for cryptogenic ischemic stroke. Stroke. 2009 40: 1499-1501.

6 Scott EM, Ariëns RAS, Grant PJ. Genetic and environmental determinants of fibrin structure and function. Relevance to clinical disease. Arterio scler Thromb Vasc Biol. 2004; 24: 1558-1566.

7 Zhou 0, Liao JK. Statins and cardiovascular diseases: from cholestero lowering to pleiotropy. Curr Pharm Des. 2009; 15: 467-478.

8 Undas A, Celinska-Lowenhoff M, Kaczor M, et al. New nonlipid effects of statins and their clinical relevance in cardiovascular disease. Thromb Haemost. 2004; 91: 1065-1077.

9 Hart RG. What's new in stroke? The top 10 studies of 2006-2008 Part II. Pol Arch Med Wewn. 2008; 118: 747-755.

10 Undas A, Brummel-Ziedins KE, Mann KG. Statins and blood coagulation. Arterioscler Thromb Vasc Biol. 2005; 25: 287-294.

11 Ramcharan AS, van Stralen KJ, Snoep JD, et al. HMG-CoA reductase inhibitors, other lipid-lowering medication, antiplatelet therapy, and the risk of venous thrombosis. J Thromb Haemost. 2009; 7: 514-520.

12 Sorensen HT, Horvath-Puho E, Sogaard KK, et al. Arterial cardiovascular events, statins, low-dose aspirin and subsequent risk of venous thromboembolism: a population-based case-control study. J Thromb Haemost 2009; 7: 521-528.

13 Undas A, Celinska-Lowenhoff M, Lowenhoff T, Szczeklik A. Statins, fenofibrate, and quinapril increase clot permeability and enhance fibrinoysis in patients with coronary artery disease. J Thromb Haemost. 2006; 4: $1029-1036$

14 Mills JD, Ariëns RA, Mansfield MW, et al. Altered fibrin clot structure in the healthy relatives of patients with premature coronary artery disease. Circulation. 2002; 106: 1938-1942.

15 von dem Borne PA, Meijers JCM, Bouma BN. Feedback activation of factor XI by thrombin in plasma results in additional formation of throm bin that protects fibrin clots from fibrinolysis. Blood. 1995; 86: 3035-3042.

16 Lisman T, Leebeek FWG, Mosnier LO, et al. Thrombin-activatable fibrinolysis inhibitor deficiency in cirrhosis is not associated with increased plasma fibrinolysis. Gastroenterology. 2001; 121: 131-139.

17 Maison P, Mennen L, Sapinho D, et al. D.E.S.I.R. Study Group. A pharmacoepidemiological assessment of the effect of statins and fibrates on fibrinogen concentration. Atherosclerosis. 2002; 160: 155-160.

18 Balk EM, Lau J, Goudas LC, et al. Effects of statins on nonlipid serum markers associated with cardiovascular disease: a systematic review. Ann Intern Med. 2003: 139: 670-682.

19 Krysiak R, Okopien B, Herman ZS. Effects of HMG-CoA reductase inhibitors on coagulation and fibrinolysis processes. Drugs. 2003; 63: 1821-1854

20 Salonen EM, Vartio T, Hedman K, et al. Binding of fibronectin by the acute phase C-reactive protein. J Biol Chem. 1984; 259: 1496-1501.

21 Fatah K, Hamsten A, Blombäck B, Blombäck M. Fibrin gel network characteristics and coronary heart disease: relations to plasma fibrinogen concentration, acute phase protein, serum lipoproteins and coronary atherosclerosis. Thromb Haemost. 1992; 68: 130-135.

22 Undas A, Plicner D, Stepien E, et al. Altered fibrin clot structure in patients with advanced coronary artery disease: a role of $\mathrm{C}$-reactive protein lipoprotein(a), and homocysteine. J Thromb Haemost. 2007; 5: 1988-1990.

23 Undas A, Brożek J, Jankowski M, et al. Plasma homocysteine affects fibrin clot permeability and resistance to lysis in human subjects. Arterioscler Thromb Vasc Biol. 2006; 26: 1397-1404.

24 Undas A, Stepien $E$, Tracz W, et al. Lipoprotein(a) as a modifier of $f$ brin clot permeability and susceptibility to lysis. J Thromb Haemost. 2006; 4: $973-975$

25 Sjoland JA, Sidelmann JJ, Brabrand M, et al. Fibrin clot structure in patients with end-stage renal disease. Thromb Haemost. 2007; 98: 339-345.

26 Dembowski E, Davidson MH. Should every patient with diabetes receive a statin? Pol Arch Med Wewn. 2008; 118: 398-401.

27 Weisel JW, Litvinov RI. The biochemical and physical process of fibrinolysis and effects of clot structure and stability on the lysis rate Cardiovasc Hematol Agents Medicinal Chem. 2008; 6: 161-180.

28 Undas A, Brummel K, Musial J, et al. Simvastatin depresses blood clotting by inhibiting activation of prothrombin, factor V, and factor XIII and by enhancing factor Va inactivation. Circulation. 2001; 103: 2248-2253. 


\title{
Simwastatyna zwiększa przepuszczalność skrzepu i wrażliwość na lizę u osób z cholesterolem LDL poniżej 3,4 mmol/1
}

\author{
Anetta Undas', Roman Topór-Mądry², Wiesława Tracz ${ }^{1}$ \\ 1 Instytut Kardiologii, Uniwersytet Jagielloński, Collegium Medicum, Kraków \\ 2 Instytut Zdrowia Publicznego, Uniwersytet Jagielloński, Collegium Medicum, Kraków
}

\section{SŁOWA KLUCZOWE}

cholesterol, fibrynoliza, skrzep fibrynowy, statyny
Adres do korespondencji: prof. dr hab. med. Anetta Undas, Instytut Kardiologii, Uniwersytet Jagielloński, Collegium Medicum, ul. Prądnicka 80 31-202 Kraków, tel.: 012-614-30-04, fax: 012-423-39-00,

e-mail:mmundas@cyf-kr.edu.pl Praca wptynęta: 23.04.2009. Przyjęta do druku: 07.05.2009 Nie zgłoszono sprzeczności interesów.

Pol Arch Med Wewn. 2009; 119 (6): 354-359

Copyright by Medycyna Praktyczna, Kraków 2009

\section{STRESZCZENIE}

WPROWADZENIE Statyny wykazują dodatkowe korzystne działania, w tym osłabienie mechanizmów prozakrzepowych. U chorych dużego ryzyka sercowo-naczyniowego ze znacznie zwiększonym stężeniem cholesterolu lipoprotein małej gęstości (low-density lipoprotein - LDL), simwastatyna potrafi zmniejszyć powstawanie trombiny i osłabić reakcje krzepnięcia katalizowane przez ten enzym. Również opisaliśmy poprawę po leczeniu simwastatyną właściwości sieci fibrynowej, ostatniego etapu krzepnięcia krwi.

CELE Ocena właściwości fibryny u pacjentów z cholesterolem LDL $<3,4 \mathrm{mmol} / \mathrm{l}$ leczonych simwastatyną.

PACJENCI I METODY W badaniu wzięło udział 30 pacjentów (24M, 6K) do 70 roku życia z cholesterolem $\mathrm{LDL}<3,4 \mathrm{mmol} / \mathrm{l}$ bez incydentów sercowo-naczyniowych w wywiadzie. Wykluczono chorych na cukrzycę, przewlekłe choroby zapalne i niewydolność nerek. Przed i po 3 miesiącach stosowania simwastatyny $40 \mathrm{mg} / \mathrm{d}$ oznaczano przepuszczalność fibryny i sprawność lizy zakrzepu w metodach ex vivo.

WYNIKI Simwastatyna powodowała znamienny spadek stężenia cholesterolu całkowitego, cholesterolu LDL, triglicerydów i białka C-reaktywnego (C-reactive protein - CRP), a stężenie fibrynogenu nie uległo zmianie. Po zastosowaniu simwastatyny obserwowano zwiększenie przepuszczalności skrzepu fibrynowego o 4,4\% ( $p<0,001$ ) oraz przyśpieszenie jego lizy $011,2 \%$ ( $p<0,001$ ) w porównaniu z wartościami przed włączeniem leku. Zmiany te korelowały ze zmniejszeniem CRP po simwastatynie. Wzrost przepuszczalności skrzepu wywołany simwastatyną był związany tylko z wiekiem i spadkiem stężenia CRP ( $R^{2}$ dla modelu $\left.=0,61\right)$, podczas gdy skrócenie czasu lizy obserwowane po simwastatynie było związane jedynie z redukcją stężenia triglicerydów i $\operatorname{CRP}\left(\mathrm{R}^{2}\right.$ dla modelu $\left.=0,62\right)$.

WNIOSKI Simwastyna wykazuje wyjątkowe właściwości polegające na ułatwieniu lizy fibryny i zwiększeniu przepuszczalności skrzepu u pacjentów z cholesterolem $\operatorname{LDL}<3,4 \mathrm{mmol} / \mathrm{l}$, które mają związek z jej działaniem przeciwzapalnym. Zmiana właściwości fibryny może przyczyniać się do klinicznych efektów statyn. 